\title{
Factors That Affect Customers Willingness to Use Self Service Technologies at Hospitality Organizations
}

\author{
Neven Sherif Abd El-Haleam \\ High Institute of Tourism and Hotels-(EGOTH)
}

\begin{abstract}
:
Many hotels and restaurants have installed self service check in out and have recently provided new self service technologies. To successfully implement and use self service technologies, it is important for the hospitality operators to understand the factors that determine both willingness and resistance of the customers to use self service technologies. Thus, the purpose of this study is to explore factors that affect customers willingness to embrace the usage of self service technologies. Comprehensive understanding of customers behavior related to their demographic factors and readiness will promote successful implementation of new SSTs as well as effective modifications of existing SSTs. Structural equation modeling was conducted to test hypotheses with a sample of 180 consumers. The results indicate that consumer's extrinsic motivation had the most significant impact on their likelihood of using new SSTs. Also, younger customers and those who do not believe in interactions with employees at hospitality industry were also more likely to use these SSTs.
\end{abstract}

Keywords: self service technology (SST)

\section{Introduction:}

The use of self service technologies SST is evolving as more hotels and restaurants adopt the technology and seek new applications for it. ${ }^{(\mathbf{1})}$ Many major hotel chains have followed the lead set by airlines and installed self service kiosks to expedite their check in process. ${ }^{(2)}$ It appears that hotels are trying to lever this trend in technology. For example, implement a self service ordering device at each of the pool lounge chairs as a way to improve guest service levels. ${ }^{\cdot(3)}$ Also, touch screen tables for food and bar orders were recently adopted to meet the younger customers' needs. ${ }^{(4)}$ Benefits of using SST opportunities from implementing SSTs appear to have strong preference because of there is cost savings involved in operators. ${ }^{(5)}$ Some hotels could increase selling by providing more products or services available on the screen of a kiosk without increasing labor costs. ${ }^{(6)}$ Furthermore, using SSTs will assist hospitality operators to increase customer retention, displaying more personalized information on the kiosk screen or other devices. ${ }^{\cdot(7)}$ Also, SST gave shorter wait times, the feeling of control and the privacy. ${ }^{(8)}$ Moreover a number of people can be served by a single employee. ${ }^{(9)}$

\section{The impact of consumer readiness to use SST:}

Consumer readiness is defined as a condition in which a consumer is prepared and likely to use an innovation for the first time. ${ }^{(\mathbf{1 0})}$ Processing high levels consumer readiness is likely to lead to usage of new technology; On the other hand low levels of readiness may slow down the usage. ${ }^{(11)}$ Understanding customer readiness is specifically significant to the adoption of new technology at hospitality settings because of service inseparability and variability. Service inseparability means that customers are a part of the product, indicating that a customer must know how to use SST service variability means that service quality depends on who provides them and when and where they are provided. ${ }^{(\mathbf{1 2})}$

\section{Role clarity:}

Role clarity refers to how well a consumer understands what role or performance is required to adequately produce a service using SSTs. ${ }^{(13)}$ since services in the hospitality industry are usually provided by employees, the usage of SSTs requires new consumer coproduction behavior. In addition, many SSTs are performed separately from service employees or other customers, thus reduced the opportunity for customers to learn or observe skills to use SSTs ${ }^{(14)}$ Previous studies suggest that the consumers' participation in using an innovation can be affected by their lack of understanding of their roles in the process. Thus, if potential users of an SST understand the role to be performed (how to knowledge), they will be more likely to use it. ${ }^{(15)}$

\begin{abstract}
Ability:
The ability concept relates to what an individual can do rather than knowing how to do it. Ability also refers to having the necessary skills required to perform a certain task. ${ }^{(16)}$ Industrial psychology literature has supported the relationship between ability and the performance of a task. ${ }^{(17)}$ Other previous research proposed that the adoption of technology is influenced by users' ability to develop the basic skills and their perceived confidence in the ability to engage in specific tasks. ${ }^{(\mathbf{1 8})}$ Similarly, ${ }^{(\mathbf{1 9})}$ It is contended that customers who use SSTs are usually found to have a high level of self efficacy in using technology and assumes that the likelihood of using SSTs will be affected by perceptions of individual capability to perform the task.
\end{abstract}




\section{Extrinsic and intrinsic motivation:}

Having alternative service delivery options available (human or SST), it is necessary to understand how to encourage customers to put their additional effort to produce service through the use of SSTs. This encouragement may come in the form of either extrinsic or intrinsic motivation. ${ }^{(20)}$ According to ${ }^{(21)}$ self determinant theory, extrinsic motivation refers to doing something because it leads to a distinguishable outcome, and intrinsic motivation refers to doing something because it is inherently interesting or enjoyable. Moreover, extrinsic is motivational forces as increased pay, cost savings, time savings, promotions, and other fringe benefits and intrinsic is motivational forces as feelings of accomplishments, personal growth, or others that related to the pleasure of engaging in the activity ${ }^{(22)}$

It was found that there is a significant relationship between extrinsic motivation (incentives) and performance of life insurance salesmen. ${ }^{(23)}$ Also revealed that extrinsic motivation, such as pay and promotions, is superior to intrinsic motivation in predicting employee effort. ${ }^{(24)}$ Moreover that extrinsic motivation is necessary if the intrinsic motivation is not sufficient to motivate consumers to use SSTs. It is rational to assume that offering extrinsic rewards, such as price discount or fast transaction, will increase the likelihood of using SST ${ }^{\cdot(25)}$

Intrinsic motivation has been found to affect an individual's technology acceptance level. It was found that intrinsic motivation has a significant direct effect on the intention to use computers in the workplace. ${ }^{(26)}$ Similarly ${ }^{(27)}$ found the support for a positive relationship between perceived enjoyment and internet usage. In the hospitality Industry, some customers will find participation in the production of service via SSTs to be intrinsically attractive. Therefore, it is appropriate to assume that consumers with high intrinsic remarks, such as enjoyment or empowerment, will be more likely to use SSTs

\section{The impact of individual difference on likelihood of using SSTs}

It was found that females with children and single males aged 40 years and younger were most likely to use SSTs ${ }^{(28)}$ Also, consumers who use new technology tend to be male, younger, and more educated. ${ }^{(29)}$ It was revealed that females are increasingly using technology, there by limiting influence of genders differences in technology adoption behavior. ${ }^{(30)}$

The positive impact of previous experience on the technology adoption play an important role in the likelihood of using SSTs. ${ }^{(31)}$ The familiarity with technology from experience reduces the cognitive effort required to use it, thus increasing the likelihood of using it. Additionally, it is has been found that early adopters of technology are more likely to use new technology. Also, experienced users require little introduction to understand how to use a software ${ }^{(32)}$

Package whereas inexperienced users needed significant help. means that the users with a higher level of computer experience will be more likely to try the new software ${ }^{(33)}$

\section{Need for interaction:}

Is defined as a consumer's desire to have personal contact with others during service encounters ${ }^{(34)}$ It was found that the need for interaction with service employees has a negative impact on the attitude toward a new SST $^{(35)}$ Also, some consumers prefer to use SSTs to stay away from the interpersonal interactions if customers feel an increased need for interpersonal encounters at a hospitality industry, the need will have a negative effect on service quality of SSTs, and thus they will be less likely to use SSTs ${ }^{(36)}$ Thus the purpose of this study was to explore influential factors related to individual differences and customer readiness on the likelihood of using SSTs.

\section{Method:}

A sample was randomly selected from five star hotels in Alexandria city, including 180 customers, to collect data. A structured interviewing questionnaire was designed and consists of the following items the first item was about gender, age and education level of customers. The second item asks customers if they have ever used self service technologies (SST), hesitating of using technology for fear of making mistakes believe that using self service technologies in hospitality industry is useful and if they believe that self service technologies in hospitality industry are easy to use. The third item were adapted customers opinions about SSTs, if there are understandable instructions regarding how to use SSTs, the capability of using SSTs, if customers feel independence, enjoyment and worthwhile. The respondents were requested to respond on a five point likert scale with 5 being strongly agree and 1 being strongly disagree. The fourth item adopted the self service technologies that customers preference degree for likelihood of using SSTs such as touch screen table to order food, check in/out at hotel lobby, language translation in a conference, on line purchases, and ordering food or other service at pool areas and internet information access kiosks in a restaurant on 5 point likert type scales, the endpoints of scales were very unlikely was coded as number 2 , neutral as number 3 , likely as number 4 and very likely as number 5 . five factors were measured: role clarity, ability, extrinsic motivation, intrinsic motivation and likelihood of using SSTs to achieve that a measurement model were built according to ${ }^{(37)}$ The statements for role clarity, ability, intrinsic motivation, extrinsic motivation and the likelihood of using SSTs are used as indicators (table1). 


\section{Figure1 : Research Framework of the study}

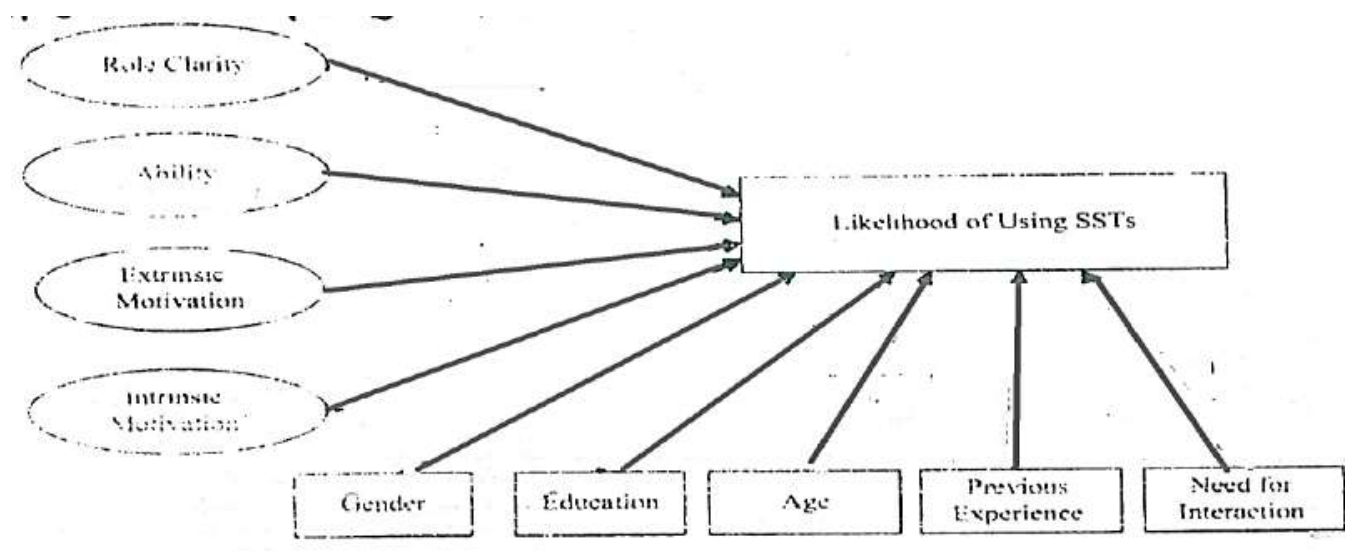

\section{Test validity:}

The questionnaire was reviewed by four professors in faculty of tourism and hotel to improve clarity of wording and to enhance the construct and content validity of the questionnaire.

Table.1 indicators in the measurement model

\begin{tabular}{|c|c|}
\hline Indicators for likelihood of using SSTs & $\begin{array}{ll}1- & \text { touch screen table to order food or other service at } \\
\text { restaurants or bars } \\
2-\quad \text { kiosks for ordering food or service at pool areas } \\
3-\quad \text { kiosks for ordering food at quick service restaurants } \\
4- & \text { kiosks for ticket redemption or cash change. } \\
\end{array}$ \\
\hline Indicators of ability & $\begin{array}{ll}1- & \text { I believe I am fully capable of using SSTs. } \\
2- & \text { I am confident in my ability to use SSTs. } \\
3- & \text { Using SSTs is well within the scope of my abilities. }\end{array}$ \\
\hline Indicators of role clarity & $\begin{array}{l}\text { 1- usually there are understandable instructions } \\
\text { regarding how to use SSTs in a hospitality industry. } \\
2-\quad \quad \text { I know what is expected from me if I use SSTs } \\
3-\quad \text { The steps in the process of using SSTs in } \\
\text { hospitality setting are clear to me. }\end{array}$ \\
\hline Indicators of extrinsic motivation & $\begin{array}{l}\text { 1- when I am in hospitality industry, convenience while } \\
\text { ordering services/ making transactions is desirable. } \\
2-\quad \text { When I conduct transactions in hospitality industry } \\
\text { being able to do them fast is desirable } \\
3-\quad \text { When I conduct transactions in hospitality industry } \\
\text { being able to conduct them when ever I want is desirable }\end{array}$ \\
\hline Indicators of intrinsic motivation & $\begin{array}{l}\text { 1- When I conduct a transaction using SSTs in } \\
\text { hospitality industry, a personal feeling of worthwhile } \\
\text { accomplishment is desirable } \\
\text { 2- When I conduct a transaction using SSTs in } \\
\text { hospitality industry, a personal feeling of enjoyment (e.g } \\
\text { cool and fun) is desirable. } \\
\text { 3- when I conduct a transaction using SSTs in a feeling } \\
\text { of independence is desirable }\end{array}$ \\
\hline
\end{tabular}

\section{Test reliability:}

The value of reliability odd was 0.94 and it's a statistical value. 


\section{Statistical analysis:}

Data was fed to the computer using FoxPro data and SPSS version 16.0 for tabulation and analysis as follows: percentage, means and SD used for continuous variables. T.test was used to compare two means of continuous variables, and path coefficient $(\beta)$ was used.

\section{Results:}

Table 2. Shows that more than half of the sample were male $(60.0 \%)$ and $53.30 \%$ of the sample were of 33 to 43 years old Most of the respondents had graduate degree $(88.30 \%)$

\begin{tabular}{|c|c|c|}
\hline Gender & N. & \% \\
\hline Male & 108 & 60.0 \\
\hline Female & 72 & 40.0 \\
\hline Age & & \\
\hline $19-32$ & 15 & 8.4 \\
\hline $33-43$ & 96 & 53.3 \\
\hline $44-63$ & 69 & 38.30 \\
\hline Education: & & \\
\hline Undergraduate degree & 5 & 2.80 \\
\hline Graduate degree & 159 & 88.30 \\
\hline Postgraduate degree & 16 & 8.90 \\
\hline
\end{tabular}

Table 3. shows the distribution of the sample according to likelihood of using self service technologies. $94.4 \%$ of the sample believe that using SSTs is useful and $88.3 \%$ of them didn't fear of making mistakes. This consider a reasonable percentage. Aspasilly, It was found that fear of making mistakes has negative effect on using self service technologies. ${ }^{(38)}$

Table 3. Distribution of the sample according to likelihood of using SSTs

\begin{tabular}{|l|c|c|c|c|}
\hline Statement & \multicolumn{2}{|c|}{ Yes } & \multicolumn{2}{c|}{ No } \\
\hline You ever used any self service technologies & $\mathrm{n}$. & $\%$ & $\mathrm{n}$. & $\%$ \\
\hline It is important to you to interact with employees in a hotel or restaurant & 129 & 71.7 & 51 & 28.3 \\
\hline $\begin{array}{l}\text { You hesitate to use most forms of technology for fear of making mistakes } \\
\text { you cannot correct }\end{array}$ & 69 & 38.3 & 111 & 61.7 \\
\hline Using self service technologies in a hospitality industry is useful. & 21 & 11.7 & 159 & 88.3 \\
\hline You believe that self service technologies in hospitality industry are easy to use. & 170 & 94.4 & 10 & 5.5 \\
\hline
\end{tabular}

Table 4 shows the opinion of using self service technologies in hospitality setting. Most of the sample (82.8\%) strongly agree that using SSTs gave a feeling of enjoyment. Almost half of the sample (53.8\%) strongly agree that always there are understandable instructions regarding how to use SSTs. 53.8\% of the sample agree that there are fully capable of using SSTs. Also, ${ }^{(39)}$ found that if customers feel capable of using SSTs. this will have a positive effect on using it, and thus will be more likely to use it. 
Table 4. Distribution of the sample according to their opinions about self service technologies in hospitality

\begin{tabular}{|c|c|c|c|c|c|c|c|c|c|c|}
\hline \multirow[t]{2}{*}{ Statement } & \multicolumn{2}{|c|}{$\begin{array}{l}\text { Strongly } \\
\text { disagree }\end{array}$} & \multicolumn{2}{|c|}{ Disagree } & \multicolumn{2}{|c|}{$\begin{array}{c}\text { Neither } \\
\text { disagree } \\
\text { nor agree }\end{array}$} & \multicolumn{2}{|c|}{ Agree } & \multicolumn{2}{|c|}{$\begin{array}{l}\text { Strongly } \\
\text { agree }\end{array}$} \\
\hline & $\mathrm{Fr}$ & $\%$ & $\mathrm{Fr}$ & $\%$ & $\mathrm{Fr}$ & $\%$ & $\mathrm{Fr}$ & $\%$ & $\mathrm{Fr}$ & $\%$ \\
\hline $\begin{array}{l}\text { Usually there are understandable } \\
\text { instructions regarding how to use } \\
\text { SSTs }\end{array}$ & 8 & 44 & 27 & 15.4 & 5 & 2.8 & 156 & 86.6 & 97 & 5.8 \\
\hline $\begin{array}{c}\text { I know what is expected from me if I } \\
\text { use SSTs. }\end{array}$ & 9 & 5.0 & 71 & 89.40 & 70 & 38.9 & 163 & 90.5 & 70 & 38.9 \\
\hline $\begin{array}{c}\text { The steps in the process of using SSTs } \\
\text { are clear to me }\end{array}$ & 4 & 2.2 & 27 & 5.6 & 54 & 30.0 & 102 & 56.7 & 71 & 39.4 \\
\hline $\begin{array}{l}\text { I believe I am fully capable of using } \\
\text { SSTs. }\end{array}$ & 5 & 2.8 & 27 & 15.0 & 85 & 47.3 & 97 & 53.8 & 99 & 55.0 \\
\hline $\begin{array}{l}\text { I am confident in my ability to use } \\
\text { SSTs }\end{array}$ & 7 & 3.8 & 26 & 14.4 & 54 & 30.0 & 99 & 55.8 & 54 & 30.0 \\
\hline $\begin{array}{l}\text { Using SSTs is well within the scope } \\
\text { of my abilities }\end{array}$ & 2 & 101 & 18 & 10.0 & 27 & 15.0 & 97 & 53.8 & 70 & 38.9 \\
\hline $\begin{array}{l}\text { When I am convenience while } \\
\text { ordering services or making } \\
\text { transactions is desirable }\end{array}$ & 7 & 3.8 & 27 & 15.0 & 70 & 38.9 & 163 & 90.5 & 70 & 38.9 \\
\hline $\begin{array}{l}\text { When I conduct transactions, being } \\
\text { able to do them fast is desirable. }\end{array}$ & 10 & $\begin{array}{l}5 \\
.5\end{array}$ & 54 & 30.0 & 27 & 15.0 & 159 & 88.3 & 70 & 38.9 \\
\hline $\begin{array}{l}\text { When I conduct transactions, being } \\
\text { able to conduct them whenever I want } \\
\text { is desirable. }\end{array}$ & 13 & 7.3 & 24 & 13.3 & 54 & 30.8 & 103 & 54.3 & 157 & 87.2 \\
\hline $\begin{array}{l}\text { When I conduct a transactions using } \\
\text { SSTs setting personal feeling of } \\
\text { worthwhile accomplishment is } \\
\text { desirable. }\end{array}$ & 2 & 1.1 & 18 & 10.0 & 54 & 30.0 & 99 & 55.8 & 99 & 55.0 \\
\hline $\begin{array}{l}\text { When I conduct a transaction using } \\
\text { SST a personal feeling of enjoyment } \\
\text { (e.g, cool and fun) is desirable. }\end{array}$ & 4 & 2.2 & 5 & 2.8 & 26 & 14.4 & 171 & 95.0 & 149 & 82.8 \\
\hline $\begin{array}{l}\text { When I conduct a transaction using } \\
\text { SST, a feeling of independence is } \\
\text { desirable. }\end{array}$ & 9 & 5.0 & 26 & 14.4 & 54 & 30.0 & 102 & 56.7 & 99 & 55.0 \\
\hline
\end{tabular}


Table 5. Shows the preference degree of likelihood of using SST. $88.9 \%$ very likely use touch screen table to order food, $95.0 \%$ very likely order food or other service at pool areas. Also, more than half of the sample $(55.0 \%-56.7 \%)$ very likely use vending machines and ATMs. respectively. This results agree with ${ }^{(40)}$ who found that $60 \%$ of the respondent being very likely to use them.

Table 5 Distribution of the sample according to the preference degree of likelihood of using SST

\begin{tabular}{|c|c|c|c|c|c|c|c|c|c|c|}
\hline \multirow{2}{*}{$\begin{array}{l}\text { Statement } \\
\text { Price checker in shopping malls }\end{array}$} & \multicolumn{2}{|c|}{$\begin{array}{c}\text { Very } \\
\text { unlikely }\end{array}$} & \multicolumn{2}{|c|}{ Unlikely } & \multicolumn{2}{|c|}{ Neutral } & \multicolumn{2}{|c|}{ Likely } & \multicolumn{2}{|c|}{ Very likely } \\
\hline & 7 & 3.8 & 16 & 8.9 & 70 & 38.9 & 70 & 38.9 & 16 & 8.9 \\
\hline Kiosks for car rental return & 5 & 2.8 & 13 & 7.3 & 54 & 30.0 & 102 & 5607 & 99 & 55.0 \\
\hline Kiosk for theater ticketing & 2 & 1.1 & 5 & 2.8 & 64 & 35.5 & 123 & 68.3 & 47 & 26.2 \\
\hline $\begin{array}{l}\text { Check in/out kiosks at a hotel } \\
\text { lobby }\end{array}$ & 5 & 2.8 & 13 & 7.3 & 171 & 95.0 & 103 & 39.4 & 85 & 47.3 \\
\hline $\begin{array}{l}\text { Airline check in/boarding pass } \\
\text { printing kiosks at a hotel lobby or } \\
\text { via internet }\end{array}$ & 10 & 5.0 & 24 & 13.3 & 85 & 47.3 & 71 & 39.4 & 85 & 47.5 \\
\hline $\begin{array}{l}\text { kiosks for language translation at } \\
\text { a ferance }\end{array}$ & 4 & 2.2 & 17 & 9.4 & 160 & 88.9 & 54 & 30.0 & 149 & 82.8 \\
\hline $\begin{array}{l}\text { Internet information access kiosks } \\
\text { in a hotel lobby, convention } \\
\text { center, or other public venues. }\end{array}$ & 2 & 1.1 & 4 & 2.2 & 27 & 15.0 & 159 & 88.3 & 103 & 57.3 \\
\hline Internet information access kiosks & 8 & 4.4 & 27 & 15.0 & 102 & 56.7 & 99 & 55 & 123 & 68.3 \\
\hline $\begin{array}{l}\text { Touch screen table to order food } \\
\text { or other service at restaurants }\end{array}$ & 5 & 2.8 & 19 & 10.6 & 70 & 38.9 & 97 & 53.8 & 160 & 88.9 \\
\hline $\begin{array}{l}\text { Kiosks for ordering food or other } \\
\text { services at pool areas }\end{array}$ & 2 & 1.1 & 17 & 9.4 & 85 & 47.3 & 159 & 88.3 & 171 & 95.0 \\
\hline $\begin{array}{l}\text { Kiosks for ordering food at quick } \\
\text { service restaurants }\end{array}$ & 7 & 3.8 & 27 & 15.0 & 156 & 86.6 & 170 & 94.4 & 102 & 56.7 \\
\hline DVD kiosks at a hotel & 6 & 3.4 & 13 & 7.3 & 102 & 56.7 & 163 & 90.5 & 101 & 56.2 \\
\hline Kiosks for cash change & 4 & 3.2 & 24 & 13.3 & 71 & 39.4 & 170 & 94.4 & 103 & 57.3 \\
\hline Vending machines & 2 & 1.2 & 13 & 7.3 & 70 & 38.9 & 102 & 56.7 & 99 & 56.0 \\
\hline ATMs & 3 & 107 & 7 & 3.8 & 99 & 55.0 & 103 & 57.3 & 102 & 56.7 \\
\hline $\begin{array}{l}\text { Voice } \\
\text { systems }\end{array} \quad$ automated $\quad$ response & 5 & 2.8 & 6 & 3.4 & 70 & 38.9 & 85 & 47.3 & 99 & 55.0 \\
\hline Pay at the pump (gas) & 2 & 1.2 & 8 & 4.4 & 97 & 53.8 & 70 & 38.9 & 85 & 47.2 \\
\hline $\begin{array}{l}\text { Internet self help (medical. } \\
\text { Computer support, etc.) }\end{array}$ & 5 & 2.8 & 7 & 3.8 & 70 & 38.9 & 103 & 57.3 & 159 & 88.3 \\
\hline
\end{tabular}




\begin{tabular}{|l|l|l|l|l|l|l|l|l|l|l|}
\hline $\begin{array}{l}\text { On line purchases (travel } \\
\text { bookings, retail) }\end{array}$ & 4 & 3.2 & 6 & 3.4 & 70 & 38.9 & 149 & 82.8 & 70 & 38.9 \\
\hline $\begin{array}{l}\text { PDAs/ smart phones for ordering } \\
\text { food or other services }\end{array}$ & 2 & 1.2 & 7 & 3.8 & 71 & 39.4 & 103 & 57.3 & 99 & 55.0 \\
\hline
\end{tabular}

Table 6. shows the mean and standard deviation for likelihood of using self service technologies to understand different levels of preference toward each SST. The mean values of likelihood of using each SST were sorted from most preferable to least preferable SSTs. As a result, pay at the pump, online purchase (e.g. travel bookings and retail), in room check out, and ATMs were the SSTs used often (higher than 1.0 mean values in likelihood). More than $80 \%$ of the respondents were likely or very likely to use these SSTs.

SSTs with mean values of likelihood between 3.5 and 4.0 were the following: internet self help (medical, computer support, etc.) vending machines, airline check- in/ boarding pass printing kiosks at the hotel lobby or via internet, price checker in shopping malls, check out kiosks at grocery stores or other retail outlets, check in/check out kiosks at a hotel lobby, kiosks for ordering food at quick service restaurants, touch screen table to order food or other services at restaurants or bars, and internet information access kiosks in the hotel lobby, convention center, or other public venues. Approximately $60 \%$ to $70 \%$ of the respondents were likely or very likely to use these SST.

SSTs with mean values of likelihood ranging from 3.0 to 3.5 were the following: kiosks for ticket redemption or cash change, kiosks for ordering food or other, kiosks for theater ticketing, kiosks for car rental return, voice automated response systems, and DVD kiosks at the hotel lobby, supermarket, or other locations. About $40 \%$ to $57 \%$ of the respondents were likely or very likely to use these SSTs.

The least preferable SSTs (with less than 3.0 mean values in likelihood) include the following: PDAs/ smart phones for ordering food or other services, kiosks for language translation at a business center, and internet information access kiosks in a bar. For these SSTs, only $22 \%$ to $29 \%$ of the respondents were likely or very likely to use them.

Table 6. Mean and standard deviation of likelihood of using SSTs

\begin{tabular}{|c|c|c|}
\hline SSTs & Mean & SD \\
\hline Pay at the pump at gas stations & 4.47 & 0.891 \\
\hline On line purchases (e.g, travel bookings, retail) & 4.22 & 1.001 \\
\hline In room check out & 4.1 & 0.996 \\
\hline ATMs & 4.06 & 1.229 \\
\hline Vending machines & 3.94 & 1.035 \\
\hline Internet self help (e.g. medical, computer support) & 3.91 & 1.11 \\
\hline via internet & 3.84 & 1.268 \\
\hline Price checker in shopping malls & 3.71 & 1.295 \\
\hline Check in/out kiosks at a hotel lobby & 3.67 & 1.168 \\
\hline Kiosks for ordering food at quick service at restaurants & 3.6 & 1.185 \\
\hline Touch screen table to order food or other service at restaurants & 3.6 & 1.185 \\
\hline
\end{tabular}




\begin{tabular}{|c|c|c|}
\hline $\begin{array}{l}\text { Internet information access kiosks in a hotel lobby, convention } \\
\text { center, or other public venue }\end{array}$ & 3.58 & 1.178 \\
\hline Kiosks for ticket redemption or cash change at a casino & 3.45 & 1.365 \\
\hline Kiosks for ordering food or other service at pool areas & 3.43 & 1.22 \\
\hline Kiosks for theater ticketing & 3.42 & 1.265 \\
\hline Kiosks for car rental return & 3.32 & 1.276 \\
\hline Voice automated response systems & 3.32 & 1.125 \\
\hline DVD kiosks at the hotel lobby, supermarket. Or other location & 3.19 & 1.301 \\
\hline $\begin{array}{c}\text { Ability to use PDAs/ smart phones for ordering food or other } \\
\text { services }\end{array}$ & 2.78 & 1.313 \\
\hline Kiosks for language translation at a business center & 2.76 & 1.254 \\
\hline Kiosks for language translation at a business center & 2.76 & 1.254 \\
\hline Internet information access kiosks in a bar & 2.42 & 1.264 \\
\hline
\end{tabular}

Table 7. Shows coefficient $\beta$ and t value, where significantly positive directs of role clarity, extrinsic motivation, and intrinsic motivation on likelihood of using SSTs were observed. The results indicate that consumers who believed that SSTs provide clear instructions for users and understand the instructions clearly were more likely to use SSTs. Similarly, consumers who showed higher levels of extrinsic motivation (i.e., convenience faster transactions and no time constraint ) and intrinsic motivation(i.e., feeling of accomplishment, enjoyment and independence) in using SSTs were more likely to use SSTs On the other hand ,age and need for interaction had significantly negative direct effects on likelihood of using SSTs. That is, consumers who believe that interaction with personnel at hospitality setting is important were less likely to use SSTs than consumers who do not. Older consumers (i.e., at the age of 43 years and older) were also less likely to use SSTs compared with the younger consumers (i.e., age between 19 and 43 years).

Table 7. Distribution of the sample according to coefficient $\beta$ and $t$ value.

\begin{tabular}{|c|c|c|}
\hline Item & coefficient $(\boldsymbol{\beta})$ & T value \\
\hline On likelihood of using SSTs of role clarity & 175 & 1.930 \\
\hline Of ability & -.031 & -.402 \\
\hline Of extrinsic motivation & 0.453 & $5.119^{*}$ \\
\hline Of intrinsic motivation & 0.147 & $1.972^{*}$ \\
\hline
\end{tabular}




\begin{tabular}{|c|c|c|}
\hline Of need for interaction & -.122 & -3.246 \\
\hline Of education & 0.135 & 1.267 \\
\hline Of experience & -.009 & -.129 \\
\hline Of age & -.282 & $-3.593 *$ \\
\hline Of gender & -.120 & -1.788 \\
\hline Of education & -.009 & -.129 \\
\hline Of experience & .135 & 1.267 \\
\hline Of need for interaction & -0.222 & -3.070 \\
\hline
\end{tabular}

$* \mathrm{p}<.05$

The final model with significant standardized regression coefficients $\beta$ is presented in figure 2; dotted arrow indicates an insignificant relationship.

Figure 2. Final model

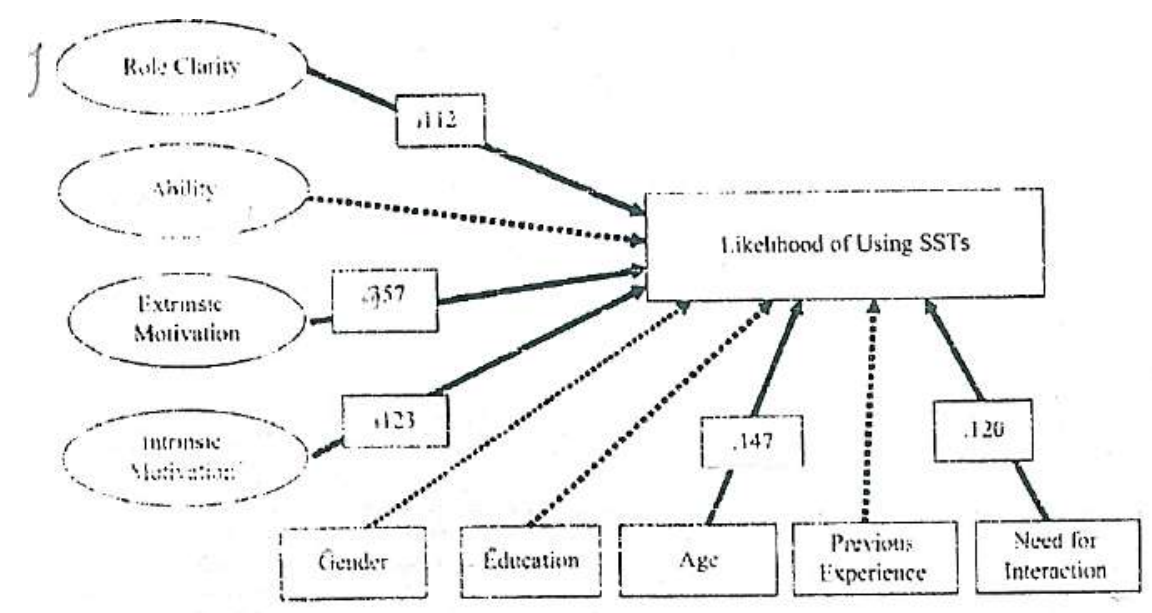

\section{Conclusion:}

The results in this study indicated that the majority of the sample believe that using SSTs is useful. Also, most of the sample strongly agree that using SSTs in hospitality industry gave a feeling of enjoyment. Most of the sample were very likely to use touch screen table to order food. Older consumer ( 43 years and older) were less likely to use SSTs compared with younger consumers ( 19 and 43 years)

\section{Recommendations:}

Based on the results the following recommendations could be suggested

- Self service technology must provide clear instructions to understand the steps and other expected roles.

- Adding function allowing users to cancel their process within next 12hours to help decrease their fears of making mistakes.

- Assisting consumers by having an employee standing by a kiosk, this approach can take care of the perception of the need for interaction since the employee is ready to interact with the customers.

- Providing SSTs in areas where younger customer usually go to such casual restaurants, because they are more likely to use SSTs than older customer. 


\section{References:}

- kasvana, M. L. and Connolly, D. j. (2005). Self service kiosks: hotels expand guest services. The bottomline, $20,14-17$.

- Connolly, D. J. (2005). In self service takes off: hospitality industry self service technology study. Edgell com pp. 200202

- Collis, B. (2006) Tele-learning in a digital age. The future of distance learning. London: international Thomson computer press., pp- 100- 101.

- Globerson, S. and maggard, m. J. (1991). A conceptual model of self service. International journal of operations \& production management, 11 (4), 33.43.

- Shellens, T. and valcke, M. (2000) Re engineering conventional university education: Implications for students' learning styles. Distance education 21 (2), 361-384.

- Cho, W. and schmelzer, C.D. (2000) just in time education: tools for hospitality managers of the futures International journal of Contemporary Hospitality Management 12 (1), $31-36$.

- Hammond, M. (2000) Communication within online forums: the opportunities, the constraints and the value of a communicative approach. Computers and Education 35, 251-262.

- Binter, M. J., Brown S. W. and Meuter, M. L. (2000). Technology infusion in service encounters. Journal of the Academy of Marketing Science, 28, 138- 149.

- Ho, S. and ko, Y. (2008). Effects of self service technology on customer value and customer readiness: the case of internet banking. Internet research, 18, 427- 446.

- Rogers, E. M. (2003). Diffusion of innovations ( $5^{\text {th }}$ ed.) Simon and Schncider press Newyork, Pp 78-80

- Hair, J. F.; black, W.C.; bablin, B. J.; Anderson, R.E. and Tathem, R. L. (2006). Multivariate data analysis. Upper saddle river, Newyork. Pp. $203-204$

- Kotler, p., Bowen, J. T. and Makens, J. C. (2006). Marketing for hospitality and tourism (4 ${ }^{\text {th }}$ ed.). Upper saddle river, nj:. Newyork Pp. 20 - 22.

- Hitz M.N. (2002) Information and Communication Technologies in Tourism, verlag, press. Pp. 30 - 35.

- Martinez, M. and Bunderson, C.V. (2000) Building interactive web learning environments to match and support individual learning differences. Journal of Interactive learning research 11 (2), 77- 93.

- Larson, R. and Bowen, D. E. (1989). Organization and customer: managing design and coordination of service. Academy of Management Review, 14, 213- 233.

- Lijander, v. Gillberg. F., Gummerus, J. and Riel, A.V. (2006). Technology readiness and the evaluation and adoption of self service technologies. Journal of Retailing and consumer services, p 13,177-182.

- Cho, W.; schmelxer, C.D. and Mcmahon, P.S. (2002) Preparing Hospitality managers for the 21st century: the merging of just in time education, critical thinking, and collaborative learning. Journal of Hospitality and Tourism Research 26 (1), $23-37$.

- Meuter, M. L.; Binter, M. J.; Ostrom, A. L. and Brown, S. W. (2005). Choosing among alternative service delivery modes: an investigation of customer trial of self service technologies. Journal of Marketing, 69, $61-83$.

- Walker, $\quad$ R. H.; Craig H. Hecker, R. Hancis, H. (2002). Technology enabled service delivery an investigation of reasons affecting customer adoption and rejection. International Journal of Service Industry Management, 13, 91 - 106.

- Fawcett, G. L. and Lockwood, A. (2000) Improving the learning environment for the development of hospitality accountancy skills using computer simulation gaming. Journal of Tourism and Hospitality Research 2 (3), $260-276$.

- Feenberg, A. (2002) The Written word on the theory and practice of computer conferencing. Pergamon press. Pp, 243 244.

- Staw, B.M. (2006). Intrinsic and Extrinsic motivation. Morristown: general learning press. Pp. 87 - 88.

- Tam, M. (2000) Constructivism, instructional design and technology Implications for transforming distance learning. Educational Technology and Society 3 (2), 50 - 60.

- Harasim, L. (2000) Shift happens online education as a new paradigm in learning The Internet and Higher Education 3 (1-2), 41 -61.

- Gagne, M., and Deci, E. (2005). Self determinant theory and work motivation. Journal of organizational Behavior, 26, 331 -362.

- Abrami, P.C. and Bures, E.M. (2005) Computer supported collaborative learning and distance education. American Journal of Distance Education 10 (2), 37- 42.

- Teo,T. S. H., Lim, V. K. G., and Lai, R. y. C. (2004). Intrinsic and extrinsic motivation in internet usage. Omega, 27, 25- 38.

- Sim, 1. 1., and koi. S. M. (2002). Signapore's internet shoppers and their impact on traditional shopping patterns. Journal of Retailing and Consumer Service, 9, 115- 124. 
- Connolly, D. J., \& Werbitt, J. M. (2005). Service on demand: resort guests can get it all the Botomime, 20, 23 - 26.

- Campos, M., Laferriere, T. and Harasim, 1. (2001) The post secondary networked classroom, renewal of teaching practices and social interaction. Journal of Asynchronous Learning Networks 5 (2), 36 -52.

- Baum, T. and Sigala, M. (2001) E - Learning in hospitality and tourism. Education, Singapore's knowledge industry journal, Decem, 32 -34.

- Bernard R., Rubalcava B. and Pierre, D. (2000) Collaborative online distance learning: issues for future practice and research. Distance Education 21 (2), 260 -277.

- Donnell, A., (2000) An Electronic Tutorial: a teaching innovation for tourism management studies. International Journal of Tourism Research 2, 367 -374.

- Porras, H. (2000) Student variables in the evaluation of mediated learning environments. Distance Education 21 (2), 385 $-403$.

- Venkatesh, v., Morris, M. G., Davis, G. B., and Davis, F. D. (2003). User acceptance of information technology: toward a unified view. MTs Quarterly, 27, $425-478$.

- Atan, H, Azil, N. Rahman, Z., and Idrus, R. (2002). Computer in distance education gender differences in self perceived computer competencies. Journal of Educational Media, 27, 123- 135.

- Byrne, B. (2006).Structural equation model with EQS: basic concepts, applications, and programming (2 ${ }^{\text {nd }}$ ed.). Mahwah, NJ: Erlbaum. Pp. 150- 155.

- Zeithaml, V. A., and Gilly, M.C. (2007). Characteristics affecting the acceptance of Retailing, technology: A comparison of elderly and nonelderly consumers .Journal Retailing . 63, 49- 68.

- Meuter, M. L., Ostrom, A. L., Roundtree, R. L., and Binter, M. J. (2000). Self service technologies: understanding customer satisfaction with technology based service encounters. Journal of Marketing, 64, 50 -64.

- Dabholkar, P. A. (2008). Consumer evaluations of new technology based self service options: an investigation of alternative models of service quality. International Journal of Research in Marketing, 13, 29- 51.

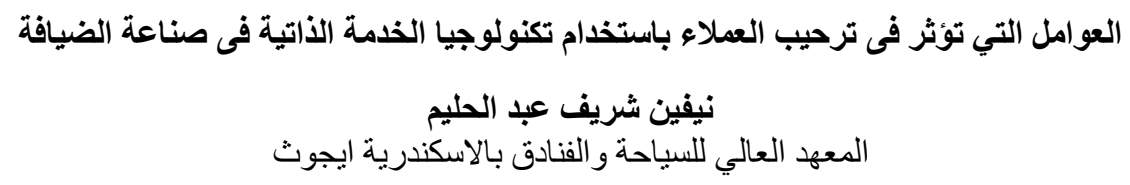

يستخدم عدد من الفنادق و المطاعم نظام الخدمة الذاتية، ولكى يحقق هذا النظام النجاح المطلوب لابد من در اسة العو امل التى تؤثر فى مدى ترحيب

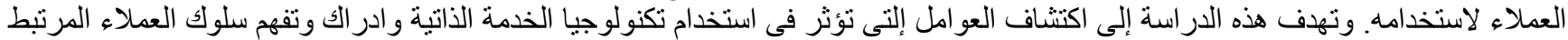
بتقبل هذا النظام. وقد تم تصميم استمارة لعينة عشو ائية قوامها 180عميل وأوضحت النتائج أن العملاء صغار السن أكثر تقبلا لنظام تكنولوجيا 